THE KURUME MEDICAL JOURNAL

1974 Vol.21, No.2-3, P.75-81

\title{
THE COMPARATIVE STUDY ON NUCLIDES FOR TUMOR SCANAGENTS (PART 1)
}

\author{
KIYOSHI YANO AND HISAMITSU KOGA \\ Department of Radiology, Yanagawa Public Hospital, \\ Yanagawa, Japan

\begin{abstract}
MIICHIRO OZEKI, YASUTO FURUKAWA AND YASUHIKO SAKAI
Department of Radiology, Kurume University School of Medicine, Kurume, Japan
\end{abstract}

(Received for publication August 22, 1974)

\begin{abstract}
We reported that the comparison of tumor affinity agents in experiment. The nuclides using tumor scanning have a distinctive character respectively. Then we should be considered sufficiently the distinctive character in taking tumor scintigram.
\end{abstract}

We have studied the diagnosis of malignant tumors, using various nuclides up to this time. These has mainly been performed by means of Kurume System color scanning ${ }^{6)}$, that was developed by Ozeki. According to the development of radioisotopes, various nuclides begin to be used in diagnosis of malignant tumors.

At this time, we picked up the nuclides used routinely as a tumor-scanning agents, that is ${ }^{67} \mathrm{Ga}$ citrate, ${ }^{169} \mathrm{Yb}$ citrate, ${ }^{57} \mathrm{Co}$ Bleomycine ( $\left.{ }^{57} \mathrm{Co} \mathrm{BLM}\right)$, and ${ }^{203} \mathrm{HgCl}_{2} .{ }^{67} \mathrm{Ga}$ citrate was first reported by Edward, C. L. and Hayes, R. L. ${ }^{1)}$ in 1969 , ${ }^{169}{ }^{9} \mathrm{~b}$ citrate by Hisada and $\mathrm{Ando}^{3)}$ in $1972,{ }^{57} \mathrm{Co}$ BLM by Maeda ${ }^{4)}$ and Nouel, J. P. ${ }^{5)}$ in $1971,{ }^{203} \mathrm{HgCl}_{2}$ by Rymer, M. ${ }^{7)}$ in $1967,{ }^{203} \mathrm{HgCl}_{2}$-glutathione by $\mathrm{Hara}^{2)}$ in 1970. Since that time, there are a lot of clinical reports with these nuclides, which are confirmed the position as tumor affinity substances.
But we have founded that there were a few difference in the deliniation of a tumor and even in the situation of the tumor in our clinical use of these tumor affinity substance. Then we have studied the comparison of these nuclides in experiment and clinicals, and discussed.

\section{PART 1 ANIMAL EXPERIMENT}

\section{I) Methods}

Ehrlich ascites tumor was inplanted into subcutaneous in the femur of dd strain mouse.

When the subcutaneous tumor raise about $2 \mathrm{~cm}$. in diameter, nuclide was injected into pertonial cavity of mouse and 72 hours after these mice was sacrified by ether, and macroradioautography and microradioautography was performed. On the other hand, the distribution of nuclides in the various tissues was counted, and a adhesionsrate to 
human serum albumin was estimated, and the tumor uptakesrate was calculated by pulse hight analyser.

1) Macroradioautography

The material sacrified by ether was fixed by aceton-dryice and sliced in $50 \mu$, and sliced preparation was exposed to $\mathrm{X}$-film.

2) Microradioautography

The tumor extirpated was fixed by freezing method in one part, by parafine in the other part of the tumor.

Freezing fixed specimen was prepared in $15 \mu$ and parafine fixed one was in $5 \mu$.

These specimen was covered by celloidin and then exposed by means of dipping method, using atomic emulsion, Sakura NR-M $\mathrm{M}_{2}$, and got after dyeing.

3) Nuclide distribution in various tissues

Nuclides in various tissues were counted by autowelltype counter and countingrate was calculuted in $1 \mathrm{~g}$ wet weight of tissue.

4) Uptakesrate in the tumor tissue

Two sorts of nuclide was simultanousely injected into peritoneal cavity of a mouse, that was inplanted Ehrlich ascites carcinoma into femursubcutane, and examination was performed 72 hours after injection. The combination of two sorts of nuclides were as follow, that is: ${ }^{67} \mathrm{Ga}$ citrate, and ${ }^{57} \mathrm{Co} \mathrm{BLM},{ }^{203} \mathrm{HgCl}_{2}$ and ${ }^{169} \mathrm{Yb}$ citrate, ${ }^{203} \mathrm{Hg} \mathrm{Cl}_{2}$ and ${ }^{67} \mathrm{Ga}$ citrate.

Two sorts of nuclides were simultanousely injected into peritoneal cavity of a mouse for the purpose of avoiding individual difference. The nuclides in the tumor were calculated by 400 channel pulse hight analyser, and drawn spectrogram. The calculation of spectrogrum was used $182 \mathrm{kev}$ of $\gamma$-ray in ${ }^{67} \mathrm{Ga}$ citrate $117 \mathrm{kev}$ in ${ }^{169} \mathrm{Yb}$ citrate, $122 \mathrm{kev}$ in ${ }^{57} \mathrm{Co}$ BLM, and $279 \mathrm{kev}$ in ${ }^{203} \mathrm{Hg}^{\circ} \mathrm{Cl}_{2}$. The uptakesrate was estimated at area of each half value width.
5) Adhesionrate to human serum albumin

$0.2 \mu \mathrm{c} / \mathrm{ml}$ of nuclide was added to $1 \mathrm{ml}$ of $25 \%$ human serum albumin, and boilded and centrifuged. Supernatant and sediment were separately counted by welltypecounter. And uptakesrate in sediment means adhesionsrate to human serum albumin.

\section{II) Results}

1) macroradioautography (Fig. 1)

a) ${ }^{67} \mathrm{Ga}$ citrate (Fig. 1-a)

The distribution in whole body was more rich in liver, spleen, lung and kidney than in tumor. In tumor, nuclides located in circumference in it.

b) ${ }^{169} \mathrm{Yb}$ citrate (Fig. 1-b)

The distribution in whole body was characteristically rich in bone. In tumor, nuclide located liked island.

c) ${ }^{57}$ Co BLM (Fig. 1-c)

The distribution in whole body was more rich in liver and kidney than in tumor, In tumor, nuclide located mottled.

d) ${ }^{203} \mathrm{Hg}^{\circ} \mathrm{Cl}_{2}$ (Fig. 1-d)

The distribution in whole body was more rich in kidney and liver than in tumor. In tumor, nuclide located homogenously.

2) microradioautography

${ }^{67} \mathrm{Ga}$ citrate was accumulated in cytoplasm (Fig. 2), ${ }^{169} \mathrm{Yb}$ citrate in near cell membrane (Fig. 3), ${ }^{57}$ Co BLM in plotoplasm (Fig. 4), and ${ }^{203} \mathrm{HgCl}_{2}$ in cytoplasm (Fig. 5).

3 ) Nuclide distribution in tissues (Table 1)

Nuclide distribution ratio of the various tissues to the tumor tissue showed in Table 1.

a) ${ }^{67} \mathrm{Ga}$ citrate

The accumulation of nuclides in liver, spleen and lung were more rich than in tumor. In the other tissue, the accumulation was below a half of that in tumor. 
The tissue in minimum accumulation was brain.

b) ${ }^{169} \mathrm{Yb}$ citrate

The distribution of nuclide in bone was more rich than in tumor.

The tissues in minimum accumulation was brain and muscle.

c) ${ }^{57} \mathrm{Co}$ BLM citrate

The distribution of nuclide in liver was more rich than in tumor.

The tissue in minimum accumulation was brain.

d) ${ }^{203} \mathrm{Hg}_{\mathrm{Cl}}$

The distribution of nuclide in kidney and liver were more rich than in tumor.

The tissue in minimum accumulation was brain.

TABLE 1

The distribution of nuclides in various tissues tumor was estimeted at $100 \%$

\begin{tabular}{l|c|c|c|c}
\hline & ${ }^{57} \mathrm{Ga}$ citrate & ${ }^{169} \mathrm{Yb}$ citrate & ${ }^{57} \mathrm{Co}$ BLM & ${ }^{203} \mathrm{HgCl}_{2}$ \\
\hline Trumor & $100 \%$ & $100 \%$ & $100 \%$ & $100 \%$ \\
Brain & 4 & 13 & 7 & 9 \\
Lung & 101 & 25 & 32 & 50 \\
Liver & 388 & 97 & 162 & 221 \\
Spleen & 148 & 39 & 81 & 87 \\
Intestine & 66 & 23 & 22 & 46 \\
Kidney & 26 & 14 & 81 & 594 \\
Bone & 55 & 298 & 22 & 32 \\
Muscle & 37 & 3 & 27 & 9 \\
\hline
\end{tabular}

(Mouse, Ehrlich ascites tumor)

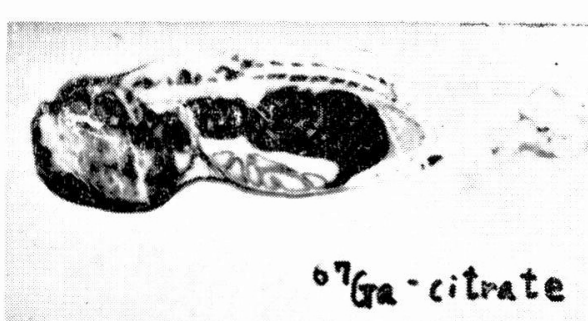

a)

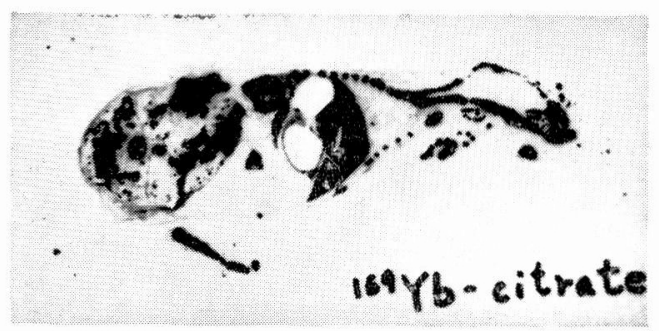

b )

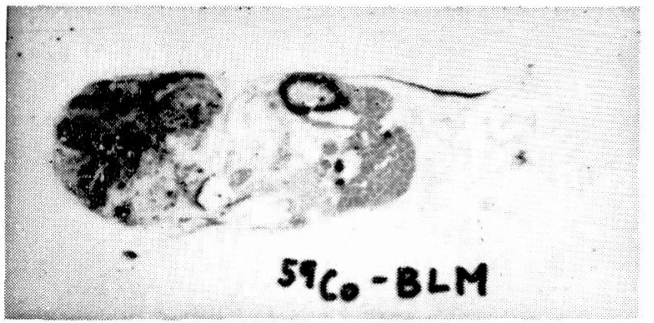

c)

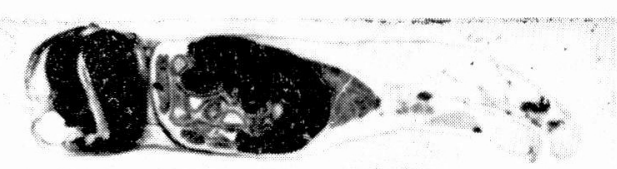

${ }^{203} \mathrm{HgCl}_{2}$

d)

Fig. 1 Macroradioautography
a) : ${ }^{67} \mathrm{Ga}$ citrate
c ) : ${ }^{57} \mathrm{Co} \mathrm{BLM}$
b) : ${ }^{167} \mathrm{Yb}$ citrate
d) : ${ }^{203} \mathrm{HgC}_{2}$ 


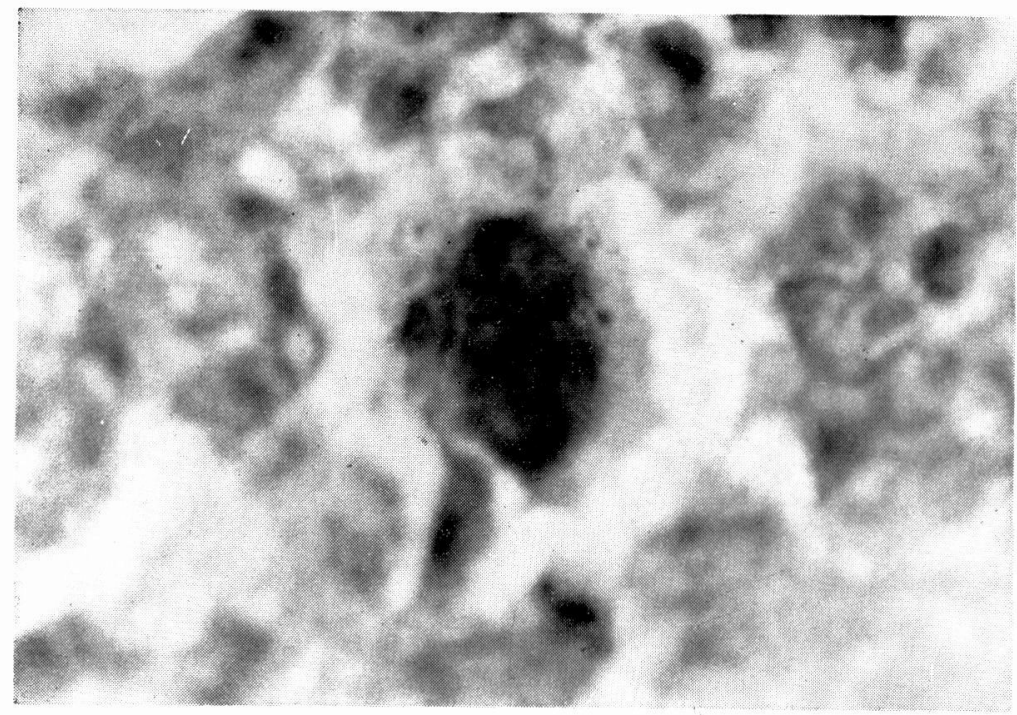

Fig. 2 Microradioautography $-{ }^{67} \mathrm{Ga}$ citrate

The silver grains were concentrated in cytoplasm.

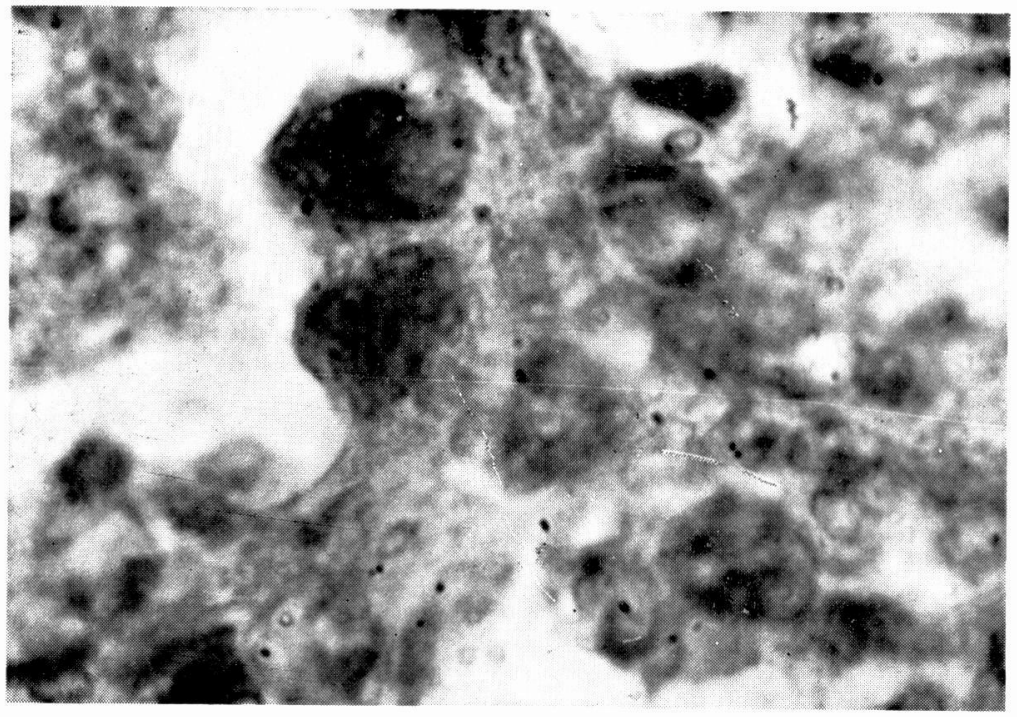

Fig. 3 Microradioautography- ${ }^{169} \mathrm{Yb}$ citrate

The silver grains were concentrated in cytoplasm. 


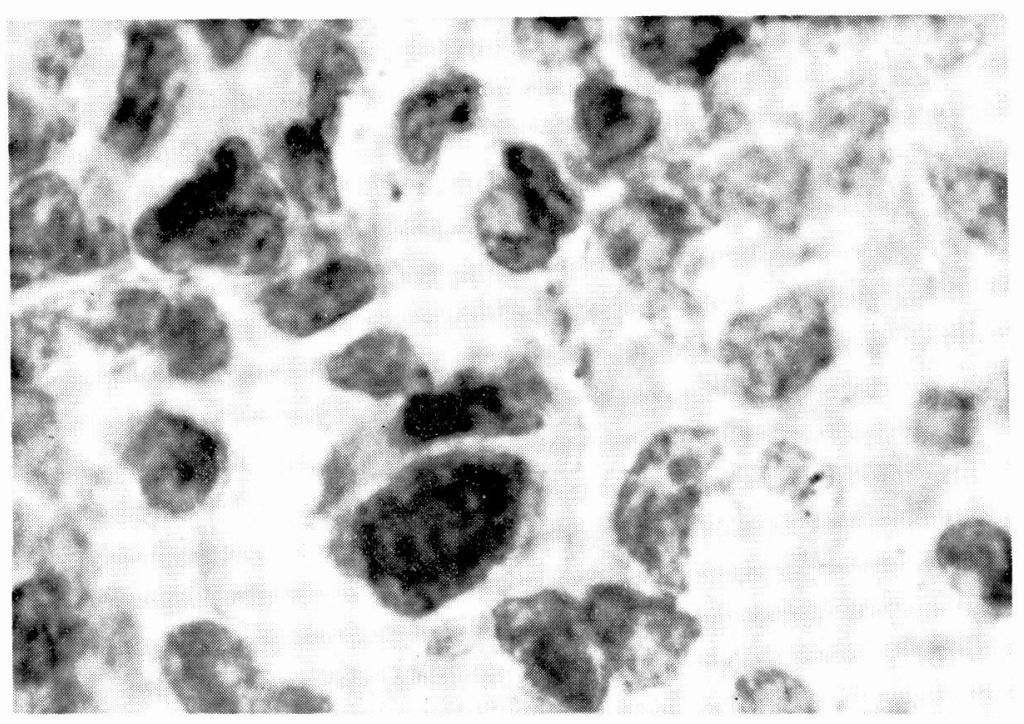

Fig. 4 Microradioautography- ${ }^{57}$ Co BLM

The silver grains were concentrated in platoplasm.

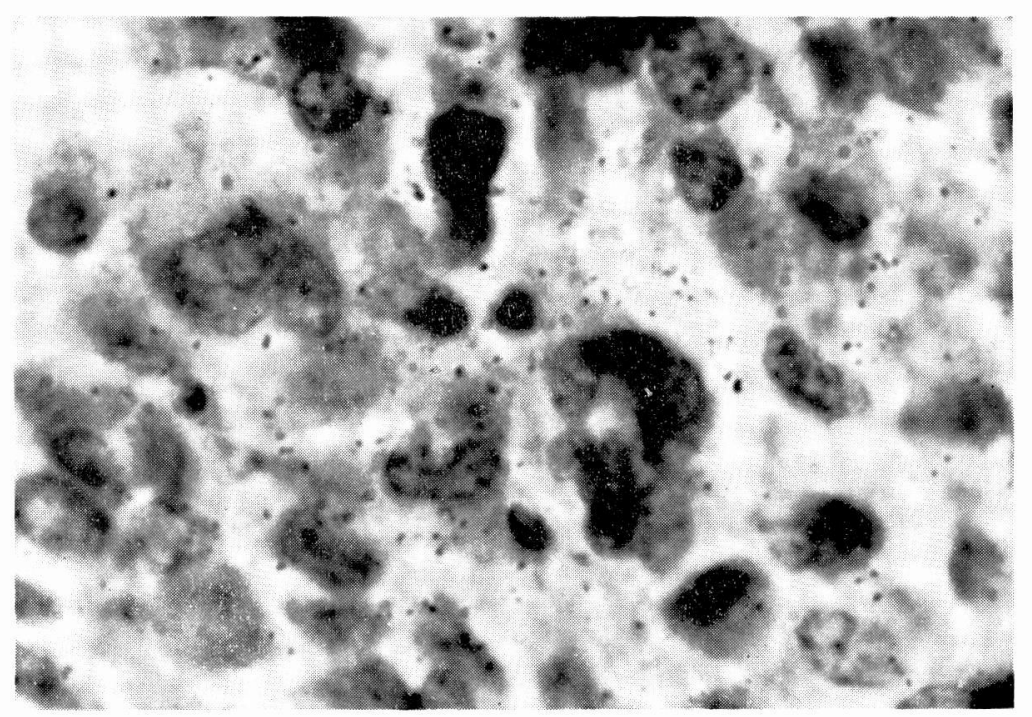

Fig. 5 Microradioautography ${ }^{203} \mathrm{Hg}^{2} \mathrm{Cl}_{2}$

The silver grains were concentrated in cytoplasm. 
TABLE 2

Uptakesrate in tumor

\begin{tabular}{c|c|c|c|c}
\hline $\mathrm{RI}$ & ${ }^{67} \mathrm{Ga}$ citrate & ${ }^{169} \mathrm{Yb}$ citrate & ${ }^{57} \mathrm{Co} \mathrm{BLM}$ & ${ }^{203} \mathrm{HgCl}_{2}$ \\
\hline & $0.46 \% / \mathrm{g}$ & 0.95 & 0.30 & 1.13 \\
$\%$ per $\mathrm{g}$. & 1.76 & 3.54 & 1.17 & 4.22 \\
& 0.99 & 1.81 & 0.75 & 2.40 \\
\hline
\end{tabular}

$(72 \mathrm{~h})$

TEN 400 channels PHA, 3 inch well type scintillator. dd Mouse, Ehrlich ascites tumor

RI. combination

$$
\begin{gathered}
{ }^{67} \mathrm{Ga}+{ }^{57} \mathrm{Co} \mathrm{BLM},{ }^{203} \mathrm{Hg}+{ }^{169} \mathrm{Yb},{ }^{67} \mathrm{Ga}+{ }^{203} \mathrm{Hg} \\
15 \mu \mathrm{Ci}+15 \mu \mathrm{Ci}
\end{gathered}
$$

4) The uptakesrate in tumor tissue (Table 2)

The uptakesrate in tumor tissue were as follow, that is, ${ }^{67} \mathrm{Ga}$ citrate was 0.46 , $1.79,0.99 \% / \mathrm{g} .{ }^{169} \mathrm{Yb}$ citrate $0.95,3.54$, $1.81 \% / \mathrm{g} . \quad{ }^{57} \mathrm{Co}$ BLM $0.30,1.17,0.75$ $\% / g .{ }^{203} \mathrm{Hg} \mathrm{Cl}_{2}$ 1.13, 4. $22,2.40 \% / \mathrm{g}$.

The estimation of uptakesrate in tumor tissue had dispersion and the estimation of uptakesrate in tumor was, as a whole, about $1 \% / \mathrm{g}$.

The nuclides in order of uptakesrate in tumor were ${ }^{203} \mathrm{HgCl}_{2},{ }^{169} \mathrm{Yb}$ citrate, ${ }^{67} \mathrm{Ga}$ citrate and ${ }^{57} \mathrm{Co}$ BLM.

5) Adhesionsrate to human serum albumin (Table 3)

Adhesionsrate to human serum albumin was $35.1 \%$ in ${ }^{67} \mathrm{Ga}$ citrate, $28.9 \%$ in ${ }^{169} \mathrm{Yb}$ citrate, $33.1 \%$ in ${ }^{57} \mathrm{Co} \mathrm{BLM}$ and $99.6 \%$ in ${ }^{203} \mathrm{Hg}^{0} \mathrm{Cl}_{2}$. Almost of all ${ }^{203} \mathrm{Hg} \mathrm{Cl}_{2}$ was adhered to human serum albumin, and the other nuclides was about $30 \%$.

TABLE 3

Adhesionsrate to human serum albumin

\begin{tabular}{c|c}
${ }^{67} \mathrm{Ga}$ citrate & $35.11 \%$ \\
${ }^{169} \mathrm{Yb}$ citrate & 28.97 \\
${ }^{57} \mathrm{Co} \mathrm{BLM}$ & 33.09 \\
${ }^{20} \mathrm{HgCl}_{2}$ & 99.61
\end{tabular}

(25\% Human serum albumin)

\section{III) Comment}

1) We observed the nuclide distribution in whole body with the radioautography and counting rate in tissues.

The distribution varied with the kinds of nuclides, for example, the highest accumulation in ${ }^{67} \mathrm{Ga}$ citrate was liver, ${ }^{169} \mathrm{Yb}$ citrate in bone, ${ }^{57} \mathrm{Co}$ $\mathrm{BLM}$ in liver, ${ }^{203} \mathrm{HgCl}_{2}$ in kidney.

Under certain tissues, nuclide accumulation rate was higher than in tumor, that is : liver, spleen and lung in ${ }^{67} \mathrm{Ga}$ citrate, bone in ${ }^{167} \mathrm{Yb}$ citrate, liver in ${ }^{57} \mathrm{Co}$ BLM, kidney and liver in ${ }^{203} \mathrm{Hg}^{0} \mathrm{Cl}_{2}$ were higher accumulation than in tumor respectively.

As above description, the distribution and accumulation varied with kinds of nuclide.

We should be considered sufficiently these findings in the case of tumor scanning and selecting nuclides.

2) Nuclide accumulation in tumor.

We observed the nuclide accumulation in tumor tissue with the microradioautography and macroradioautography.

The findings of macroradioautography showed that the accumulation in tumor varied with kinds of nuclids too, for example, ${ }^{67} \mathrm{Ga}$ citrate was located in circumference in tumor tissue, ${ }^{169} \mathrm{Yb}$ 
citrate liked island, ${ }^{57} \mathrm{Co}$ BLM mottled, ${ }^{203} \mathrm{Hg}^{3} \mathrm{Cl}_{2}$ homogenous.

But these findings have some problem, that are development time and term from nuclide injection. In this series, when development time was prolonged enough, the accumulation in tumor naturally got homogenous in all nuclides.

So we didn't think that the difference of accumulation means directly the difference of nuclide uptake into the tumor tissue.

We thought that these findings should be resolved from the other methods.

Nuclide accumulation in tumor cells by means of microradioautography was as follow, that is ; ${ }^{67} \mathrm{Ga}$ citrate, ${ }^{169} \mathrm{Yb}$ citrate and ${ }^{203} \mathrm{HgCl}_{2}$ were in cytoplasm and ${ }^{57} \mathrm{Co} B L M$ was accumulated in platoplasm.

3) Uptakesrate in the tumor tissue.

For the purpose of avoiding an individual difference, two sorts of nuclides was simultanously injected into peritoneal cavity of a mouse. Uptakesrate in the tumor tissue was calculated by 400 channel pulse hight analyser, and the results were relatively dispersed. The dispersion of value of uptake rate in tumor tissue may suggested that nuclides was not homogenously concentrated in the tumor tissue.

And the result was only indicated that uptake rate in tumor tissue was nearly $1 \%$ of injections dosis in each nuclide.
4) Adhesionsrate to human serum albumin.

In ${ }^{67} \mathrm{Ga}$ citrate, ${ }^{169} \mathrm{Yb}$ citrate and ${ }^{57} \mathrm{Co}$ BLM, adhesionsrate to human serum albumin were about $30 \%$, and ${ }^{203} \mathrm{Hg} \mathrm{Cl}_{2}$, on the contrary, was $99.6 \%$.

There was a large difference between ${ }^{203} \mathrm{Hg}^{\circ \mathrm{Cl}_{2}}$ and the others in adhesionsrate to human serum albumin.

On the other hand, the difference in uptakesrate in tumor tissue in each nuclide was not so great, so we presumed that adhesionsrate to human serum albumin did not exert the influence in nuclide uptake into the tumor tissue.

(We will report the clinical evaluation in the 2 nd part.)

\section{REFERENCES}

1) Edward, C.L. and Hayes, S.L. : J. Nucl. Med. 10, 103, 1969.

2) HARA, T. : Nikkyo, 29, 525, 1970.

3 ) Hisada, K. and Ando, A. : Igakunoayumi, 81 (13), 825, 1972.

4) MAedA, T., et al. : Radiology. 21 (2), 118, 1972.

5 ) Nouel, J.P., et al. : Nouvelle Press Medicale, 8 (2), 95, 1972.

6) OzeKi, M. : Nipp. Act. Radiol. 22 (5), 448, 1962.

7 ) RYMER, M., et al. : J. franç med. chir.thor. 21, 129, 1967. 